\title{
EFFECT OF SOIL COMPACTION AND CO-INOCULATION WITH Azospirillum brasilense ON THE DEVELOPMENT OF PEANUT PLANTS ${ }^{1}$
}

\author{
LAURA CRISTINA REZENDE DAS NEVES ${ }^{2}$, SALOMÃO LIMA GUIMARÃES $^{2 *}$, EDNA MARIA BONFIM-SILVA², \\ ANALY CASTILHO POLIZEL DE SOUZA ${ }^{2}$, DANIELA TIAGO DA SILVA CAMPOS ${ }^{3}$
}

\begin{abstract}
The aim of this study was to evaluate the effect of inoculation with rhizobium and coinoculation with Azospirillum brasilense on phytometric characteristics of peanut plants grown in Latossolo Vermelho (Oxisol) with and without compaction. The experiment was conducted in a greenhouse, with a randomized block design in a 5x2 factorial scheme and 4 replicates, totaling 40 experimental units. Treatments were composed by commercial inoculant for peanuts (SEMIA 6144 strain); MT 15 strain; combination of MT $15+$ A. brasilense; nitrogen control and absolute control. Plant height, number of leaves, number of branches per plant, stem diameter and Falker chlorophyll index were evaluated. The data were subjected to analysis of variance and, when significant, to Tukey test at $1 \%$ probability level. For the variables plant height, number of leaves, number of branches and stem diameter, the results were similar for all treatments, except for the absolute control and number of branches at 90 days after emergence (DAE) and stem diameter at 30 and 90 DAE. For stem diameter at $30 \mathrm{DAE}$, the results were similar to those found in the treatments with coinoculation, commercial inoculant and nitrogen fertilization. There was interaction for Falker chlorophyll index at $60 \mathrm{DAE}$, with the best result found in the MT 15 strain. Inoculation with MT15 and co-inoculation with $A$. brasilense promoted good performance in peanut crop in terms of phytometric characteristics in soil with and without compaction.
\end{abstract}

Keywords: Arachis hypogaea L. Nodule-forming bacteria. Associative bacteria.

\section{EFEITO DA COMPACTAÇÃO DO SOLO E DA COINOCULAÇÃO COM Azospirillum brasilense NO DESENVOLVIMENTO DE PLANTAS DE AMENDOIM}

RESUMO - O objetivo do estudo foi avaliar o efeito da inoculação com rizóbio e da coinoculação com Azospirillum brasilense nas características fitométricas de plantas de amendoim cultivado em Latossolo Vermelho com e sem compactação. O experimento foi realizado em casa de vegetação, com delineamento de blocos ao acaso em esquema fatorial 5x2, e 4 repetições, totalizando 40 unidades experimentais. Os tratamentos foram compostos por inoculante comercial para amendoim (estirpe SEMIA 6144); estirpe MT 15; a combinação MT $15+$ A. brasilense; testemunhas nitrogenada e absoluta. Foram avaliados altura de plantas, número de folhas, número de ramos por planta, diâmetro de caule e índice de clorofila Falker. Os dados foram submetidos à análise de variância e quando significativos, ao Teste de Tukey a 1\% de probabilidade. Em relação às variáveis altura de plantas, número de folhas e de ramos e diâmetro de caule os resultados encontrados foram semelhantes para todos os tratamentos, com exceção da testemunha absoluta e do número de ramos aos 90 dias após a emergência (DAE) e do diâmetro de caule aos 30 e 90 DAE. Para o diâmetro de caule aos 30 DAE houve resultados similares ao tratamento coinoculado, ao inoculante comercial e à adubação nitrogenada. Houve interação para o índice de clorofila Falker aos 60 DAE em que a estirpe MT 15 obteve o melhor resultado. A inoculação com a estirpe MT15 e a coinoculação com A. brasilense proporcionaram à cultura do amendoim bom desempenho em relação às características fitométricas em solo com e sem compactação.

Palavras-chave: Arachis hypogaea L. Bactérias nodulíferas. Bactérias associativas.

\footnotetext{
${ }^{*}$ Corresponding author

${ }^{1}$ Received for publication in 10/30/2019; accepted in 07/06/2020.

Paper extracted from the masters dissertation of the first author.

${ }^{2}$ Graduate Program in Agricultural Engineering, Universidade Federal de Rondonópolis, Rondonópolis, MT, Brazil; lauracristina_rezende@hotmail.com - ORCID: 0000-0003-3753-4594, slguimaraes@hotmail.com - ORCID: 0000-0002-6052-6122, embonfim@-hotmail.com - ORCID: 0000-0003-1989-8431, analy@ufmt.br-ORCID: 0000-0002-9743-0538.

${ }^{3}$ Faculty of Agronomy and Zootechnics, Universidade Federal de Mato Grosso, Cuiabá, MT, Brazil; camposdts@yahoo.com.br - ORCID: 0000-0001-5066-9317.
} 


\section{INTRODUCTION}

Peanut (Arachis hypogaea L.) is a legume crop rich in oil, proteins, vitamins, carbohydrates and minerals, and can be consumed fresh or used for various other purposes, such as for the manufacture of food, medicinal products and for oil extraction (LOBO et al., 2012).

It is the fourth most produced oilseed crop in the world, with China being the largest producer (USDA, 2018). In Brazil, the Southeast region is the largest producer, especially the State of São Paulo, and the Midwest, North and Northeast regions have low production (SIZENANDO et al., 2016; CONAB, 2018) but with great potential for its expansion.

Studies aimed at understanding the ability of peanut to adapt to the most varied types of stress are important, given the global relevance of this crop. Soil compaction is a stress factor that influences the balance between macropores and micropores and total porosity (TREVISAN et al., 2017), increases soil mechanical resistance (ROSSETI, CENTURION, 2018), reduces infiltration (LOURENTE et al., 2011) and root penetration (COSTA et al., 2012), besides affecting the availability of water and nutrients to plant roots (CABRAL et al, 2012). In addition, oxygen deficiency in compacted soils causes serious problems to the biological nitrogen fixation (BNF) process, especially in the formation and activity of nodules (MOREIRA, SIQUEIRA, 2006). All these interferences cause changes in the biochemical functioning of crops, restricting shoot growth (FARIAS et al., 2013) and production (ROSSETI, CENTURION, 2018).

An alternative to this process may be related to the use of microorganisms, especially nitrogenfixing and/or plant growth-promoting ones, to evaluate what benefits inoculation and coinoculation could bring to plants in a compacted environment.

Through BNF, rhizobia can increase crop yield, reduce production costs compared to the use of nitrogen fertilizers, and reduce damage to the environment (HUNGRIA; CAMPO; MENDES, 2007; MELO; ZILLI, 2009). Growth promoters, in addition to BNF, produce hormones that promote plant and root growth, supplying them with more water and nutrients present in the soil (MOREIRA; SIQUEIRA, 2006; VINHAL-FREITAS; RODRIGUES, 2010).

Thus, the objective of this study was to evaluate the effect of inoculation with rhizobium and co-inoculation with Azospirillum brasilense on the development of peanut plants grown in a Latossolo Vermelho (Oxisol) of the Cerrado region with and without compaction.

\section{MATERIAL AND METHODS}

The experiment was conducted in a greenhouse at the Federal University of Mato Grosso, Campus of Rondonópolis-MT, Brazil, located at $16^{\circ} 28^{\prime} 15^{\prime \prime}$ South latitude, $50^{\circ} 38^{\prime} 08^{\prime \prime}$ West longitude and altitude of 284 meters.

The climate of the region according to Köppen's classification is Aw, hot and humid with rains in summer and drought in winter (NIMER, 1989).

The soil used was classified as Latossolo Vermelho distrófico (Oxisol) (EMBRAPA, 2013) collected in a Cerrado area in the $0-0.20 \mathrm{~m}$ layer and sieved through a 4-mm mesh for filling the pots and 2-mm mesh for chemical and particle-size characterization (EMBRAPA, 2017).

The data obtained were: $\mathrm{pH}\left(\mathrm{CaCl}_{2}\right)=4.2 ; \mathrm{P}$ $=0.6 \mathrm{mg} \mathrm{dm}{ }^{-3} ; \mathrm{K}=23.4 \mathrm{mg} \mathrm{dm}{ }^{-3} ; \mathrm{Ca}=0.45 \mathrm{cmol}_{\mathrm{c}}$ $\mathrm{dm}^{-3} ; \mathrm{Mg}=0.25 \mathrm{cmol}_{\mathrm{c}} \mathrm{dm}^{-3} ; \mathrm{Al}=0.68 \mathrm{cmol}_{\mathrm{c}} \mathrm{dm}^{-3} ; \mathrm{H}$ $=4.70 \mathrm{cmol}_{\mathrm{c}} \mathrm{dm}^{-3} ; \mathrm{H}+\mathrm{Al}=5.38 \mathrm{cmol}_{\mathrm{c}} \mathrm{dm}^{-3} ; \mathrm{SB}=$ $0.76 \mathrm{cmol}_{\mathrm{c}} \mathrm{dm}^{-3} ; \mathrm{CEC}=6.13 \mathrm{cmol}_{\mathrm{c}} \mathrm{dm}^{-3} ; \mathrm{V}=12.40$ $\%$; OM $=25.6 \mathrm{~g} \mathrm{dm}^{-3}$; Sand $=407 \mathrm{~g} \mathrm{~kg}^{-1} ;$ Silt $=136$ $\mathrm{g} \mathrm{kg}^{-1}$; Clay $=457 \mathrm{~g} \mathrm{~kg}^{-1}$.

Acidity was corrected with dolomitic limestone (RNV 86\%) through the base saturation method (RAIJ, 1991). Base saturation was increased to $60 \%$. After the incubation period, the soil was subjected to triplicate analysis of $\mathrm{pH}$ in $0.01 \mathrm{M}$ $\mathrm{CaCl}_{2}$ (EMBRAPA, 2017).

Phosphate fertilization with $100 \mathrm{mg} \mathrm{dm}^{-3}$ of $\mathrm{P}_{2} \mathrm{O}_{5}$ and potassium fertilization with $60 \mathrm{mg} \mathrm{dm}^{-3}$ of $\mathrm{K}_{2} \mathrm{O}$ were performed using single superphosphate and potassium chloride as sources, respectively. Basal fertilization was not performed only in the absolute control (without fertilization and without inoculation).

Nitrogen fertilization was performed only in the control treatment containing nitrogen, at a dose of $50 \mathrm{mg} \mathrm{dm}^{-3}$, using urea as a source.

Complementation with micronutrients was performed using a solution containing $1 \mathrm{mg} \mathrm{dm}^{-3}$ of boron (B) and copper $(\mathrm{Cu}), 3 \mathrm{mg} \mathrm{dm}^{-3}$ of zinc $(\mathrm{Zn})$ and manganese $(\mathrm{Mn})$, and $0.2 \mathrm{mg} \mathrm{dm}^{-3}$ of molybdenum (Mo) (FARIAS et al., 2015), whose sources were boric acid $\left(\mathrm{H}_{3} \mathrm{BO}_{3}\right)$, copper sulfate pentahydrate $\left(\mathrm{CuSO}_{4} . \quad 5 \mathrm{H}_{2} \mathrm{O}\right)$, zinc sulfate heptahydrate $\left(\mathrm{ZnSO}_{4}\right.$. $\left.7 \mathrm{H}_{2} \mathrm{O}\right)$, manganese (II) chloride tetrahydrate $\left(\mathrm{MnCl}_{2} \cdot 4 \mathrm{H}_{2} \mathrm{O}\right)$ and molybdic acid $\left(\mathrm{MoO}_{3}\right)$.

The pots were assembled using the methodology suggested by Farias et al. (2013) with adaptations. Each experimental unit consisted of a 5.3 $-\mathrm{dm}^{3}$ pot, constructed with rigid PVC (polyvinyl chloride) tube, with $150 \mathrm{~mm}$ internal diameter and $300 \mathrm{~mm}$ height, consisting of three 100-mm-high rings (Figure 1), joined with silver tape. 


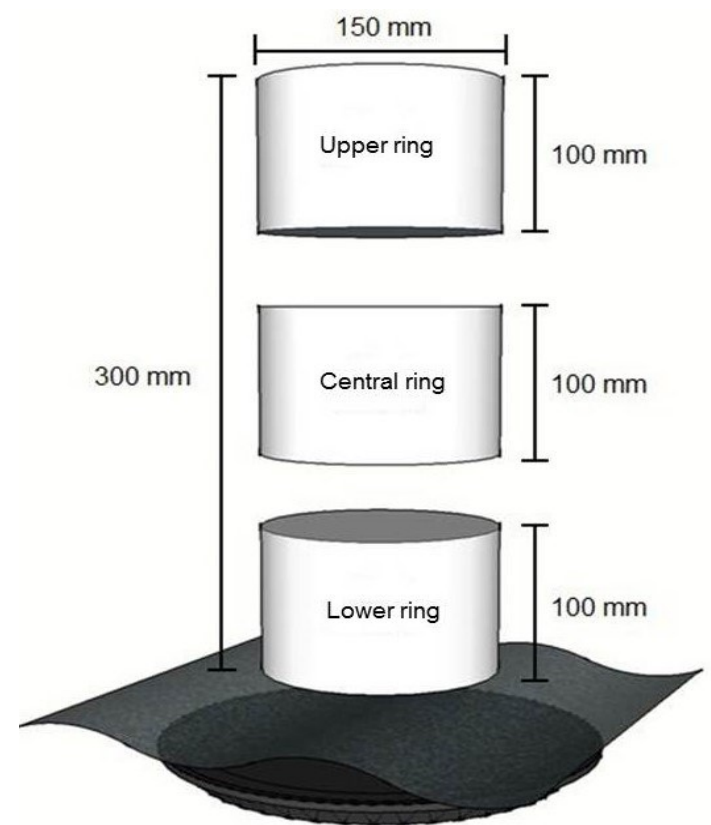

Figure 1. Illustrative scheme of the assemblage of the experimental units.

A $70 \%$ shade monofilament black net (Sombrite ${ }^{\circledR}$ ) was placed at the bottom of each pot. This net was fixed with a rubber ring obtained from the cross-section of a tire tube. Plastic plates of 300 $\mathrm{mm}$ in diameter were used under each experimental unit to serve as the bottom of the container.

In the lower ring, a 2-cm-thick layer of crushed stone was used to facilitate drainage from the pots when irrigation was applied in the upper ring.

Upper and lower rings were filled with equivalent soil mass to maintain bulk density at 1.0 $\mathrm{Mg} \mathrm{m}{ }^{-3}$ (FAGUNDES; SILVA; BONFIM-SILVA, 2014; SILVA et al., 2016 b; PALUDO et al., 2017), according to equation 1 (BONFIM-SILVA et al., 2014; FAGUNDES; SILVA; BONFIM-SILVA, 2014).

$$
\begin{aligned}
& \mathrm{BD}=\mathrm{Mds} / \mathrm{V} \\
& \text { Where: } \\
& \mathrm{BD}=\text { soil bulk density }\left(\mathrm{Mg} \mathrm{m}^{-3}\right) \text {; } \\
& \mathrm{Mds}=\text { mass of dry soil }(\mathrm{Mg}) ; \\
& \mathrm{V}=\text { total volume of the ring }\left(\mathrm{m}^{-3}\right) \text {. }
\end{aligned}
$$

In treatments with compacted soil, the central ring received a mass of soil to maintain its bulk density at $1.6 \mathrm{Mg} \mathrm{m}^{-3}$, which is considered as critical for Latossolo Vermelho (Oxisol) of the Cerrado region (NUNES; BONFIM-SILVA; SILVA, 2016).

However, in order to achieve the density corresponding to the desired compaction level, it is necessary to consider the soil moisture at the time of the compaction procedure, i.e. to facilitate the compaction process, soil moisture needs to be at an appropriate content (CAPUTO; CAPUTO, 2015).

Thus, compression tests were performed in the laboratory using the Proctor Test - NBR 7182
(ABNT, 1986) and moisture content tests, following the methodology of EMBRAPA (2017). These procedures resulted in a value of $16 \%$ (mass basis) as the ideal compression moisture for Latossolo Vermelho (Oxisol) (FAGUNDES; SILVA; BONFIM -SILVA, 2014; PALUDO et al., 2017; PALUDO et al., 2018).

Following the principle of non-uniformity of moisture contents among soil samples that were used to fill the compacted rings, the wet soil mass to be used was determined considering the moisture content of each sample, according to equation 2 (BONFIM-SILVA et al., 2014; FAGUNDES; SILVA; BONFIM-SILVA, 2014).

$$
\begin{aligned}
& \theta \mathrm{m}=(\mathrm{Mws}-\mathrm{Mds}) / \mathrm{Mds} \text { or } \mathrm{Mws}=\underset{(1+\theta \mathrm{m})}{\mathrm{Mds}} \\
& (1+2)
\end{aligned}
$$

Where:

$\theta \mathrm{m}=$ moisture content on mass basis $(\%)$;

Mws = mass of wet soil $(\mathrm{Mg})$;

$\mathrm{Mds}=$ mass of dry soil $(\mathrm{Mg})$.

After the mass of soil was properly calculated, the quantity was added to the central ring and compaction was performed using a hydraulic press.

Sowing was performed manually, using 10 seeds per experimental unit. The peanut cultivar used was IAC 503, which has a high oil content (70 to $80 \%$ ) and extended shelf life, making it an advantageous option for the consumer market of the product (IAC, 2017).

Germination occurred five days after sowing and, after thinning, four plants were left in each pot.

Soil moisture was initially maintained by irrigation, performed on the surface of the pots until 
the establishment of the plants. After irrigation, it began to be maintained by capillarity by adding water to the plates under the pots, forcing the plants to overcome the compacted layer in search of water (SILVA; MAIA; BIANCHINI, 2006).

The inoculant with MT 15 strain (R. tropici) was prepared following the methodology described by Fred and Waksman (1928), Hungria and Araújo (1994) and Melo and Azevedo (1998). Then, the rhizobium strain in liquid medium 79 was subjected to shaking $(100 \mathrm{rpm})$ and incubated at $30{ }^{\circ} \mathrm{C}$. The number of cells was adjusted to ensure the value of

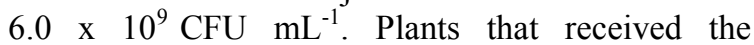
commercial inoculant (SEMIA 6144 strain of $B$. elkanii) were inoculated following the manufacturer's recommendation.

Subsequently, $3 \mathrm{~mL}$ of bacterial broth were inoculated near the root system of the plants that composed the treatment.

Co-inoculation was performed with commercial inoculant containing $A$. brasilense, strains $\mathrm{Ab}-\mathrm{V} 5$ and $\mathrm{Ab}-\mathrm{V} 6$ in the proportion of $3 \mathrm{~mL}$, also applied close to the roots of each plant. Both inoculation and co-inoculation were performed after thinning of the plants.

The experiment was conducted in a randomized block design (RBD) in a $5 \times 2$ factorial scheme. The treatments used were: commercial inoculant for peanuts (MT 15 strain; combination of MT $15+A$. brasilense; nitrogen control (with nitrogen and without inoculation) and absolute control (without fertilization and without inoculation) in soil with and without compaction. Four replicates were performed, totaling 40 plots.
Evaluations were carried out throughout the peanut crop cycle for plant height, number of leaves, number of branches per plant, stem diameter (at 30, 60 and 90 days after emergence) and Falker chlorophyll index (at 30, 45, 60, 75 and 90 days after emergence).

Plant height was determined by measuring the vertical distance between the soil surface and the tip of the main stem of the peanut plant, using a tape measure. The number of leaves was obtained by counting leaves per plant in each experimental plot. The number of branches per plant was obtained by manual counting of primary and secondary branches. Stem diameter was measured with a digital caliper. Chlorophyll index, obtained by the average readings of five leaves per plot, was determined using a portable chlorophyll meter (Falker ClorofiLOG ${ }^{\circledR}$ CFL1030).

The data were subjected to analysis of variance and, when significant, to Tukey test at $1 \%$ probability level using the statistical program SISVAR 5.6 (FERREIRA, 2014).

\section{RESULTS AND DISCUSSION}

\section{Plant height}

For plant height, there was no interaction between treatments and soil condition. The results were significant at $1 \%$ probability level for treatments and soil condition (Table 1), at 30 and 60 days after emergence.

Table 1. Plant height of peanut as a function of inoculation with rhizobium, co-inoculation with $A$. brasilense and soil condition.

\begin{tabular}{lcc}
\hline \multirow{2}{*}{ Treatments } & \multicolumn{2}{c}{ Plant height $(\mathrm{cm})$} \\
\cline { 2 - 3 } & 30 days & 60 days \\
\hline MT 15 & $23.10 \mathrm{a}$ & $28.25 \mathrm{a}$ \\
MT $15+$ A. brasilense & $23.10 \mathrm{a}$ & $26.71 \mathrm{ab}$ \\
Commercial inoculant & $22.76 \mathrm{ab}$ & $26.66 \mathrm{ab}$ \\
Nitrogen control & $23.16 \mathrm{a}$ & $29.21 \mathrm{a}$ \\
Absolute control & $20.56 \mathrm{~b}$ & $22.91 \mathrm{~b}$ \\
\hline CV $(\%)$ & 7.00 & 10.24 \\
\hline Soil condition & & Plant height $(\mathrm{cm})$ \\
\hline & 30 days ${ }^{*}$ & 60 days \\
\hline Not compacted & $23.37 \mathrm{a}$ & $28.05 \mathrm{a}$ \\
\hline Compacted & $21.71 \mathrm{~b}$ & $25.45 \mathrm{~b}$ \\
\hline CV $(\%)$ & 7.00 & 10.24 \\
\hline
\end{tabular}

Means followed by different letters in the columns differ by Tukey test at $1 \%\left(^{*}\right)$ probability level. 
In all analyses, the values found for inoculated and co-inoculated treatments did not differ from those of treatments containing nitrogen and commercial inoculant. This shows that the symbiosis between peanut plants and rhizobia alone or in association with A. brasilense (through coinoculation) was able to fix atmospheric nitrogen and provide it for plants in a similar way to nitrogen fertilizer and the inoculant for the crop available on the market.

These results further confirm the relevance of BNF for legume plants to grow and develop (HUNGRIA; CAMPO; MENDES, 2007; GUIMARÃES et al., 2016).

Santos et al. (2017) observed that the single inoculation of Bradyrhizobium japonicum and $A$. brasilense and the co-inoculation with both significantly influenced the height of peanut plants, with the highest value obtained in the co-inoculated treatment. Silva et al. (2017) obtained higher height of peanut plants, compared to the control treatment (without inoculation), in the co-inoculated treatment (B. japonicum + A. brasilense).

However, different results were found by Santos et al. (2014), who did not observe significant difference between inoculated and non-inoculated treatments in the initial growth of the peanut cultivar IAC Tatu. Muniz et al. (2016) also observed the same when working with forage peanut cv. Amarillo.

Higher value of plant height in noncompacted soil than in compacted soil is due to the fact that compaction reduces macroporosity and affects the amount of oxygen in the soil (TREVISAN et al., 2017). Thus, the oxidation of ammonium to nitrate, which corresponds to the form of greatest absorption by plants, is compromised (SHAN et al., 2012). In addition, under anoxic conditions there are losses of nitrate due to denitrification (CHANG et al., 2011).

It is also worth pointing out that the increase in soil density leads to a decrease in water flow and compromises the transport of nutrients, which occurs mainly by mass flow, as for nitrogen, or by diffusion, as for phosphorus (CABRAL et al., 2012).

Farias et al. (2013) observed a significant reduction in the height of dwarf pigeon pea plants with increasing compaction levels, corroborating the behavior of peanuts in compacted soil.

Therefore, as nitrogen is an extremely important component of biomolecules and participates in various physiological processes in the plant, its lack affects plant growth more than any other nutrient (TAIZ; ZEIGER, 2013).

In addition, Runner peanut plants, such as IAC 503, have vertical main stem with height ranging from 20 to $30 \mathrm{~cm}$ (GODOY; MINOTTI; RESENDE, 2005), corroborating the values found in the present study.

\section{Number of leaves}

The effect of inoculation and co-inoculation on the number of leaves was significant at $1 \%$ probability level in the three evaluations performed (Table 2).

Table 2. Number of leaves in peanut plants as a function of inoculation with rhizobium and co-inoculation with $A$. brasilense in soil with and without compaction.

\begin{tabular}{lccc}
\hline \multirow{2}{*}{ Treatments } & \multicolumn{3}{c}{ Number of leaves } \\
\cline { 2 - 4 } & 30 days & 60 days & 90 days \\
\hline MT 15 & $77.63 \mathrm{a}$ & $195.88 \mathrm{a}$ & $206.00 \mathrm{a}$ \\
MT 15 + A. brasilense & $82.50 \mathrm{a}$ & $192.88 \mathrm{a}$ & $218.88 \mathrm{a}$ \\
Commercial inoculant & $76.88 \mathrm{a}$ & $159.00 \mathrm{a}$ & $176.13 \mathrm{ab}$ \\
Nitrogen control & $81.38 \mathrm{a}$ & $202.13 \mathrm{a}$ & $227.63 \mathrm{a}$ \\
Absolute control & $64.00 \mathrm{~b}$ & $99.50 \mathrm{~b}$ & $126.75 \mathrm{~b}$ \\
\hline CV (\%) & 10.26 & 19.09 & 19.12 \\
\hline
\end{tabular}

Means followed by different letters in the columns differ by Tukey test at $1 \%$ probability level.

Plants inoculated with MT 15 and coinoculated with $A$. brasilense were similar to those in the nitrogen treatment and inoculated with commercial product, indicating that the nitrogen macronutrient was supplied via BNF. In addition, with the technique of co-inoculation using plant growth-promoting bacteria, several other benefits can be observed in plants, such as the development due to the production of phytohormones (DOBBELAERE; VANDERLEYDEN; OKON,
2003).

Similar results were obtained by Santos et al. (2017), who found that single and combined inoculation with $B$. japonicum and $A$. brasilense influenced the number of leaves of peanut plants.

This is because nitrogen is closely linked to the photosynthetic process, as it is a component of the chlorophyll molecule (LIN et al., 2009). Chlorophyll, however, is found inside chloroplasts, 
which are organelles present in leaves and in young stems (TAIZ; ZEIGER, 2013).

As the main function of the leaf is to perform photosynthesis through its chloroplasts (TAIZ; ZEIGER, 2013), the greater the number of leaves, the more chemical energy is produced in the form of ATP and organic molecules (KLUGE, 2008). Thus, the plant manages to perform its respiratory process and biosynthesize amino acids and plant hormones for its development (KLUGE, 2008; TAIZ; ZEIGER, 2013).

In addition, the associative bacterium $A$. brasilense, used in the co-inoculation of this study, produces phytohormones, which act on plant growth and alter root morphology, which enables greater exploitation of water and nutrients from the soil (FUKAMI; CEREZINI; HUNGRIA, 2018).

Compaction did not interfere in the number of peanut leaves, which shows that the acquisition of nutrients and water from the soil solution was not compromised by this factor. Different results were obtained by Farias et al. (2013), who observed reduction in the number of leaves in dwarf pigeon pea as soil density increased.

This may have occurred because the increase in soil mechanical resistance causes an increase in root diameter in the denser layer and favors the growth of thinner lateral roots to enter the small pores (VALADÃO et al., 2015).

\section{Number of branches per plant}

For the number of branches per plant, at 30, 60 and 90 days after emergence, the inoculated and co-inoculated treatments were significant at $1 \%$ probability level (Table 3 ).

Table 3. Number of branches in peanut plants as a function of inoculation with rhizobium and co-inoculation with $A$. brasilense in soil with and without compaction.

\begin{tabular}{lccc}
\hline \multirow{2}{*}{ Treatments } & \multicolumn{3}{c}{ Number of branches per plant } \\
\cline { 2 - 4 } & 30 days & 60 days & 90 days \\
\hline MT 15 & $24.63 \mathrm{a}$ & $56.25 \mathrm{a}$ & $58.13 \mathrm{ab}$ \\
MT 15 + A. brasilense & $25.88 \mathrm{a}$ & $55.13 \mathrm{a}$ & $60.88 \mathrm{ab}$ \\
Commercial inoculant & $24.75 \mathrm{a}$ & $46.13 \mathrm{a}$ & $49.13 \mathrm{bc}$ \\
Nitrogen control & $25.88 \mathrm{a}$ & $58.00 \mathrm{a}$ & $63.50 \mathrm{a}$ \\
Absolute control & $20.38 \mathrm{~b}$ & $30.13 \mathrm{~b}$ & $36.25 \mathrm{c}$ \\
\hline CV (\%) & 9.61 & 17.71 & 18.02 \\
\hline
\end{tabular}

Means followed by different letters in the columns differ by Tukey test at $1 \%$ probability level.

Due to its importance in the synthesis of various biological compounds, such as amino acids, proteins and nucleic acids, nitrogen is essential for the development of plant cells and tissues (FERREIRA et al., 2017; TAIZ et al., 2017). This was proven in this study, because the absolute control (without fertilization and without inoculation) had the lowest number of branches in all evaluations.

Moreover, the stress caused by compaction did not interfere in the number of branches per peanut plant, except for the absolute control, which indicates that this factor did not hamper the acquisition of nutrients and water from the soil in the other treatments. Different results were found by Leonel et al. (2007), who obtained a lower number of branches for the peanut cultivar IAC Tatu ST subjected to different levels of soil compaction. Farias et al. (2013) also observed a smaller number of branches in dwarf pigeon pea plants as soil density increased.

The treatments inoculated with the rhizobium strain MT 15 and co-inoculated with $A$. brasilense showed statistically equal results to those of the nitrogen control and the commercial product for peanut at 30 and 60 days after emergence, evidencing the importance of BNF for this crop.

These results differ from those reported by Santos et al. (2017), who did not find significant difference between the control treatment and single or combined inoculation with $B$. japonicum and $A$. brasilense for the number of branches per plant in the peanut cultivar IAC Tatu ST.

At 90 days after emergence, the treatment containing the commercial inoculant showed a similar result to that of the absolute control. This may have occurred due to the death of plants of this treatment caused by the Sclerotium wilt.

\section{Stem diameter}

Inoculation and co-inoculation with $A$ brasilense influenced stem diameter at $1 \%$ probability level in the three analyses performed (Table 4). 
Table 4. Stem diameter of peanut plants as a function of inoculation with rhizobium and co-inoculation with A. brasilense in soil with and without compaction.

\begin{tabular}{lccc}
\hline \multirow{2}{*}{ Treatments } & \multicolumn{3}{c}{ Stem diameter $(\mathrm{mm})$} \\
\cline { 2 - 4 } & 30 days $^{* *}$ & 60 days $^{* *}$ & 90 days $^{* *}$ \\
\hline MT 15 & $3.017 \mathrm{bc}$ & $3.239 \mathrm{a}$ & $3.609 \mathrm{ab}$ \\
MT 15 + A. brasilense & $3.306 \mathrm{a}$ & $3.385 \mathrm{a}$ & $4.055 \mathrm{a}$ \\
Commercial inoculant & $3.200 \mathrm{ab}$ & $3.233 \mathrm{a}$ & $3.480 \mathrm{bc}$ \\
Nitrogen control & $3.107 \mathrm{abc}$ & $3.258 \mathrm{a}$ & $3.742 \mathrm{ab}$ \\
Absolute control & $2.959 \mathrm{c}$ & $2.875 \mathrm{~b}$ & $3.081 \mathrm{c}$ \\
\hline CV (\%) & 5.21 & 4.42 & 9.11 \\
\hline
\end{tabular}

Means followed by different letters in the columns differ by Tukey test at $1 \%\left({ }^{* *}\right)$ probability level.

At 30 days after emergence, the treatments with co-inoculation, commercial inoculant and nitrogen had the same values for stem diameter. At 90 days after emergence, similar results were observed between the treatments with MT 15, association of MT $15+A$. brasilense and the nitrogen control.

The co-inoculated treatment showed satisfactory performance in relation to stem diameter. This may have occurred because, besides fixing nitrogen, $A$. brasilense also produces phytohormones such as auxins, cytokines, gibberellins, abscisic acid, among others, which are directly linked to plant growth and favor the exploitation of a greater volume of water and nutrients in the soil (FUKAMI; CEREZINI; HUNGRIA, 2018).

At 60 days, all treatments were similar, except for the absolute control, which had the lowest value, indicating that the native soil rhizobia were not efficient in the BNF process. Thus, it is clear the importance of research aimed at obtaining efficient strains that promote gains in peanut crop.

Moreover, soil compaction did not influence stem diameter in the present study, differing from the results reported by Leonel et al. (2007), who observed reduction in the stem diameter of the peanut cultivar IAC 886 as the levels of soil compaction increased.

\section{Falker chlorophyll index}

Inoculation and co-inoculation at 30 and 90 days were significant at $1 \%$ probability level (Table 5) for Falker chlorophyll index.

Table 5. Falker chlorophyll index in peanut plants as a function of inoculation with rhizobium and co-inoculation with $A$. brasilense in soil with and without compaction.

\begin{tabular}{lcc}
\hline \multirow{2}{*}{ Treatments } & \multicolumn{2}{c}{ Falker chlorophyll index } \\
\cline { 2 - 3 } & 30 days & 90 days \\
\hline MT 15 & $41.13 \mathrm{ab}$ & $54.19 \mathrm{a}$ \\
MT $15+$ A. brasilense & $42.91 \mathrm{a}$ & $52.54 \mathrm{a}$ \\
Commercial inoculant & $43.13 \mathrm{a}$ & $52.08 \mathrm{a}$ \\
Nitrogen control & $42.08 \mathrm{ab}$ & $55.14 \mathrm{a}$ \\
Absolute control & $38.30 \mathrm{~b}$ & $42.55 \mathrm{~b}$ \\
\hline CV $(\%)$ & 7.10 & 6.92 \\
\hline
\end{tabular}

Means followed by different letters in the columns differ by Tukey test at $1 \%$ probability level.

In the analyses performed at 30 and 90 days after emergence, the treatments with inoculation and co-inoculation with $A$. brasilense showed good performance, not differing from the nitrogen control and the commercial product for the peanut crop. The absolute control had the lowest result for Falker chlorophyll index, which indicates a low performance of the BNF of native soil rhizobia. In addition, the lack of nutrients in the absolute control, such as phosphorus (P), molybdenum (Mo) and boron (B), essential to BNF process (MOREIRA; SIQUEIRA, 2006), can also influence this result.

These results differ from those obtained by Santos et al. (2014), who found no significance for 
chlorophyll index among inoculated and noninoculated plants of the peanut cultivar IAC Tatu. Silva et al. (2016 a) also found no significant difference in chlorophyll a, chlorophyll b and total chlorophyll indices of peanut plants grown on distinct organic substrates and inoculated with the strain SEMIA 6144.

Thus, it can be inferred that nitrogen was efficiently supplied via BNF, because the results for Falker chlorophyll index of plants in the nitrogen control were similar to those of inoculated and coinoculated plants, reinforcing the proportionality between chlorophyll content and leaf nitrogen concentration (SILVA et al., 2010).

In addition, the stress caused by compaction did not compromise the development of peanut plants at 30 and 60 days after emergence.

At 60 days after emergence, there was interaction between treatments and soil condition at $1 \%$ probability level (Table 6).

Table 6. Falker chlorophyll index in peanut plants, at 60 days after emergence, as a function of inoculation with rhizobium and co-inoculation with $A$. brasilense in soil with and without compaction.

\begin{tabular}{lcc}
\hline \multirow{2}{*}{ Treatments } & \multicolumn{2}{c}{ Falker index at 60 days/Soil condition } \\
\cline { 2 - 3 } & Compacted & Not Compacted \\
\hline MT 15 & $55.04 \mathrm{aA}$ & $49.10 \mathrm{aB}$ \\
MT 15 + A. brasilense & $49.51 \mathrm{bA}$ & $49.67 \mathrm{aA}$ \\
Commercial inoculant & $51.67 \mathrm{abA}$ & $48.34 \mathrm{aA}$ \\
Nitrogen control & $54.30 \mathrm{abA}$ & $50.12 \mathrm{aB}$ \\
Absolute control & $39.64 \mathrm{cA}$ & $42.61 \mathrm{bA}$ \\
\hline CV (\%) & & \\
\hline
\end{tabular}

Means followed by the same letters, lowercase in the columns and uppercase in the rows, do not differ by Tukey test at $1 \%$ probability level.

In the interaction between treatments and soil condition, it was found that, for the compacted soil, the MT 15 strain led to the best value of Falker index. This result demonstrates that the strain was able to overcome the stress caused by increased soil density. This may have occurred due to the competitive efficiency of the rhizobium MT 15 in the process of root infection compared to the native soil rhizobia, which resulted in a more efficient fixation, supplying the plant with the nitrogen compounds necessary for its proper development.

Peanut can form nodules with a wide range of native rhizobia that often have high competitiveness, but low efficiency in the fixation process (SANTOS et al., 2007). This is the reason why it is so hard to establish an efficient rhizobium-peanut symbiosis (BORGES et al., 2007). The MT 15 strain has shown promising results in several studies conducted with different crops, such as pigeon pea (GUIMARÃES et al., 2016) and cowpea (SILVA et al., 2016 b), evidencing the potential for its use as an inoculant in Brazil.

Regarding the non-compacted soil, the highest values of Falker chlorophyll index were found in the treatments with commercial inoculant and co-inoculation (MT $15+$ A. brasilense).

The commercial inoculant for peanut cultivation has been on the market for 25 years and the results were expected to be satisfactory, although not observed in some variables analyzed in this study. With regard to the co-inoculated treatment, the synergistic effect between the two microorganisms led to greater accumulation of leaf nitrogen at 60 days (half of the crop cycle). This occurred because, besides fixing nitrogen, $A$. brasilense also promotes other advantages, such as the production of exudates with bioactive molecules by plants and that serve the bacterial metabolism, contributing to the nodulation process (MOREIRA; SIQUEIRA, 2006).

As Azospirillum promotes plant growth, Bashan and de-Bashan (2010) suggested the "theory of multiple mechanisms", according to which the bacterium acts cumulatively or in a standardized sequence of effects due to several simultaneous or consecutive mechanisms (FUKAMI; CEREZINI; HUNGRIA, 2018). Examples of this are: the production of phytohormones and other compounds that promote root growth and consequently result in improvements in water and nutrient absorption (ARDAKANI; MAFAKHERI, 2011); solubilization of inorganic phosphorus making it more available to plants and leveraging higher yields (TURAN et al., 2012); the aid in the mitigation of abiotic stresses, such as salinity and drought (KIM et al., 2012) and the biological control of plant pathogens (TORTORA; DÍAZ-RICCI; PEDRAZA, 2011).

\section{CONCLUSION}

Inoculation with the strain MT 15 ( $R$. tropici) and co-inoculation with $A$. brasilense positively contributed to the development of peanut plants (Arachis hypogaea L.) in relation to phytometric characteristics when cultivated in soil with and without compaction and may contribute to the sustainability of agroecosystems. 


\section{REFERENCES}

ASSOCIAÇÃO BRASILEIRA DE NORMAS TÉCNICAS - ABNT. NBR 7182: ensaio de compactação. Rio de Janeiro, 1986.

ARDAKANI, M. MAFAKHERI, S. Designing a sustainable agroecosystem for wheat (Triticum aestivum L.) production. Journal of Applied Environmental and Biological Sciences, 1: 401413, 2011.

BASHAN, Y.; de-BASHAN, L. E. How the plant growth-promoting bacterium Azospirillum promotes plant growth a critical assessment. Advances in Agronomy, 108: 77-136, 2010.

BONFIM-SILVA, E. M. et al. Wheat cultivars under bulk density levels in Cerrado Rhodic Hapludox, Central Brazil. African Journal of Agricultural Research, 9: 1641-1643, 2014.

BORGES, W. L. et al. Nodulação e fixação biológica de nitrogênio de acessos de amendoim com estirpes nativas de rizóbios. Revista Brasileira de Ciências Agrárias, 2: 32-37, 2007.

CABRAL, C. E. A. et al. Compactação do solo e macronutrientes primários na Brachiaria brizantha cv. Piatã e Panicum maximum cv. Mombaça. Revista Brasileira de Engenharia Agrícola e Ambiental, 16: 362-367, 2012.

CAPUTO, H. P. et al. Mecânica dos solos e suas aplicações. $7^{\mathrm{a}}$ ed. V.1. Rio de Janeiro, RJ: LTC, 2015. $272 \mathrm{p}$.

CHANG, C. Y. et al. Microbial community analysis of an aerobic nitrifying-denitrifying MBR treating ABS resin wastewater. Bioresource Technology, 102: 5337-5344, 2011.

COMPANHIA

NACIONAL

DE

ABASTECIMENTO - CONAB. Acompanhamento da safra Brasileira Grãos, v. 5, safra 2017/2018, n. 10, décimo levantamento, Brasília, 178 p., julho, 2018.

COSTA, M. A. T. et al. Resistência do Solo à Penetração e Produção de Raízes e de Forragem em Diferentes Níveis de Intensificação do Pastejo. Revista Brasileira de Ciência do Solo, 36: 9931004, 2012.

DOBBELAERE, S.; VANDERLEYDEN, J.; OKON, Y. Plant growth-promoting effects of diazotrophs in the rhizosphere. Critical Reviews in Plant Sciences, 22: 107-149, 2003.

EMPRESA BRASILEIRA DE PESQUISA
AGROPECUÁRIA - EMBRAPA. Manual de métodos de análises de solo. $3^{\mathrm{a}}$ ed. Brasília, DF, 2017. $575 \mathrm{p}$

EMPRESA BRASILEIRA DE PESQUISA AGROPECUÁRIA - EMBRAPA. Sistema brasileiro de classificação de solos. Brasília, DF, 2013.353 p.

FAGUNDES, E. A. A.; SILVA, T. J. A.; BONFIMSILVA, E. M. Desenvolvimento inicial de variedades de cana-de-açúcar em Latossolo submetidas a níveis de compactação do solo. Revista Brasileira de Engenharia Agrícola e Ambiental, 18: 188-193, 2014

FARIAS, L. N. et al. Concentration of nutrients and chlorophyll index in pigeon pea fertilized with rock phosphate and liming in Cerrado Oxisol. African Journal of Agricultural Research, 10: 1743-1750, 2015

FARIAS, L. N. et al. Características morfológicas e produtivas de feijão guandu anão cultivado em solo compactado. Revista Brasileira de Engenharia Agrí́cola e Ambiental, 17: 497-503, 2013.

FERREIRA, D. F. Sisvar: a Guide for its Bootstrap procedures in multiple comparisons. Ciência $\boldsymbol{e}$ Agrotecnologia, 38: 109-112, 2014.

FERREIRA, P. P. et al. Density of soil and nitrogen in production and nutrition of safflower (Carthamus tinctorius L.). Australian Journal of Crop Science, 11: 605-609, 2017

FRED, E. B.; WALKSMAN, S. A. Laboratory Manual of General Microbiology with Special Reference to the Microorganisms of the Soil. New York: Mc-Graw-Hill BookCompany, 1928.

FUKAMI, J.; CEREZINI, P.; HUNGRIA, M. Azospirillum: benefits that go far beyond biological nitrogen fixation. AMB Express, 8: 73, 2018.

GODOY, I. J.; MINOTTI, D.; RESENDE, P. L. Produção de amendoim de qualidade. Viçosa, MG: Centro de Produções Técnicas, 2005. 168 p.

GUIMARÃES, S. L. et al. Development of pigeon pea inoculated with Rhizobium isolated from cowpea trap host plants. Revista Caatinga, 29: 789-795, 2016

HUNGRIA, M.; ARAÚJO, R. S. Manual de métodos empregados em estudos de microbiologia agrícola. Brasília, DF: EMBRAPA, 1994. 542 p.

HUNGRIA, M.; CAMPO, R. J.; MENDES, I. C. . A importância do processo de fixação biológica do 
nitrogênio para a cultura da soja: componente essencial para a competitividade do produto brasileiro. Londrina, PR: EMBRAPA Soja, 2007. 80 p.

INSTITUTO AGRONÔMICO DE CAMPINAS IAC. Centro de Grãos e Fibras. Cultivares Amendoim. Disponível em: <http:// www.iac.sp.gov.br/ areasdepesquisa/graos/ amendoim.php>. Acesso em: 03 dez. 2017.

KIM, Y. C. et al. Enhancement of plant drought tolerance by microbes. In: Aroca, R. (Ed.) Plant responses to drought stress: from morphological to molecular features. Springer Verlag, Berlin, 2012, p. 383-413.

KLUGE, R. A. Fisiologia Vegetal. Fotossíntese. 2008. Disponível em: < https://social.stoa.usp.br/ articles/0016/2634/Apostila_FotossA_ntese.pdf $>$ Acesso em: maio/2018.

LEONEL, C. L. et al. Relação da compactação do solo com a cultura do amendoim. Bioscience Journal, 23: 70-81, 2007.

LIN, X. Q. et al. Effect of plant density and nitrogen fertilizer rates on grain yield and nitrogen uptake of super hybrid rice (Oryza sativa L.). Journal of Agricultural Biotechnology and Sustainable Development, 1: 44-53, 2009.

LOBO, D. M. et al. Características de deficiência nutricional do amendoinzeiro submetido à omissão de N, P, K. Bioscience Journal, 28: 69-76, 2012.

LOURENTE, E. R. P. et al. Atributos microbiológicos, químicos e físicos des olo sob diferentes sistemas de manejo e condições de Cerrado. Pesquisa Agropecuária Tropical, 41: 2028, 2011.

MELO, I. S.; AZEVEDO, J. L. Ecologia microbiana. Brasília, DF: EMBRAPA/CNPMA, 1998. 488 p.

MELO, S. R.; ZILLI, J. E. Fixação biológica de nitrogênio em cultivares de feijão-caupi recomendadas para o Estado de Roraima. Pesquisa Agropecuária Brasileira, 44: 1177-1183, 2009.

MOREIRA, F. M. de S; SIQUEIRA, J. O. Microbiologia e bioquímica do solo. 2. ed. Lavras: MG: Editora UFLA, 2006. 729 p.

MUNIZ, A. W. et al. Inoculação de rizóbios em amendoim forrageiro cv. Amarillo em Manaus, AM. Manaus, AM: Embrapa, 2016. 4 p. (Circular Técnica 56).
NIMER, E. Climatologia do Brasil. $2^{\mathrm{a}}$ ed. Rio de Janeiro, RJ: IBGE, 1989. 421 p.

NUNES, J. A. S.; BONFIM-SILVA, E. M.; SILVA, T. J. A. Bulk density and water tensions in the soil on corn root production. Revista Brasileira de Engenharia Agrícola e Ambiental, 20: 357-363, 2016.

PALUDO, J. T. S. et al. Agronomic performance of Safflower genotypes (Carthamus tinctorius L.) under different soil bulk density levels in the Oxisol of the Cerrado. Australian Journal of Crop Science. 12: 407-412, 2018.

PALUDO, J. T. S. et al. Reproductive components of safflower genotypes submited of bulk density levels in the Brazilian Cerrado. American Journal of Plant Sciences, 8: 2069-2082, 2017.

RAIJ, B. VAN. Fertilidade do solo e adubação. Piracicaba, SP: Ceres, Potafos, 1991. 343 p.

ROSSETI, K. V.; CENTURION, J. F. Use of $S$ index as a structural quality incator for campacted Latosols cultivated with maize. Revista Caatinga, 31: 455- 465, 2018

SANTOS, C. C. et al. Crescimento inicial de plantas de amendoim inoculadas com rizóbio isolado de feijão caupi. Enciclopédia Biosfera, 10: 1097-1105, 2014.

SANTOS, C. E. R. S. et al. Diversidade de rizóbios capazes de nodular leguminosas tropicais. Agrária, 2: 249-256, 2007.

SANTOS, D. M. S. et al. Bactérias fixadoras de nitrogênio e molibdênio no cultivo do amendoim em solo do Cerrado. Revista de Agricultura Neotropical, 4: 84-92, 2017.

SHAN, A. Y. K. V. et al. Assimilação metabólica de nitrogênio em plântulas de seringueira cultivadas com nitrato ou amônio. Pesquisa Agropecuária Brasileira, 47: 754-762, 2012.

SILVA, A. C. et al. Bactérias fixadoras de nitrogênio e substratos orgânicos no crescimento e índices clorofiláticos de amendoim. Revista Agrotec, 37: 18, 2016a.

SILVA, E. F. L. et al. Fixação Biológica do $\mathrm{N}_{2}$ em feijão-caupi sob diferentes doses e fontes de fósforo solúvel. Bioscience Journal, 26: 394-402, 2010.

SILVA, E. R. et al. Coinoculação de Bradyrhizobium japonicum e Azospirillum brasilense em sementes de amendoim de diferentes tamanhos. Revista de Agricultura Neotropical, 4: 
93-102, 2017.

SILVA, G. J.; MAIA, J. C. S.; BIANCHINI, A. Crescimento da parte aérea de plantas cultivadas em vaso, submetidas à irrigação subsuperficial e a diferentes graus de compactação de um Latossolo Vermelho-Escuro distrófico. Revista Brasileira de Ciência do Solo, 30: 31-40, 2006.

SILVA, N. L. et al. Effect of compactation of soil on the development and production of cowpea inoculated with rhizobium. African Journal of Microbiology Research, 10: 2007-2014, 2016 b.

SIZENANDO, C. I. T. et al. Agronomic efficiency of Bradyrhizobium in peanut under different environments in Brazilian Northeast. African Journal of Agricultural Research, 11: 3482-3487, 2016.

TAIZ, L. ZEIGER, E. Fisiologia Vegetal. 5. ed. Porto Alegre, RS: Artmed, 2013. 918 p.

TAIZ, L. et al. A Fisiologia e Desenvolvimento Vegetal. 6. ed. Porto Alegre, RS: Artmed, 2017. 858 p.

TORTORA, M. L.; DÍAZ-RICCI, J. C.; PEDRAZA, R. O. Azospirillum brasilense siderophores with antifungal activity against Colletotrichum acutatum. Archives of Microbiology, 193: 275-286, 2011.

TREVISAN, R. G. et al. Variabilidade de atributos físicos do solo de arroz cultivado sob plantas de cobertura em sistema de integração lavoura-pecuária. Revista Bragantia, 76: 145-154, 2017.

TURAN, M. et al. Yield promotion and phosphorus solubilization by plant growth-promoting rhizobacteria in extensive wheat production in Turkey. Journal of Plant Nutrition Soil Science, 175: 818-826, 2012.

\section{UNITED STATES DEPARTMENT OF AGRICULTURE - USDA. World Agricultural Production. Disponível em: $<$ https:// apps.fas.usda.gov/psdonline/circulars/ production.pdf $>$ Acesso em: 01 jul., 2018.}

VALADÃO, F. C. A. et al. A. Adubação fosfatada e compactação do solo: sistema radicular da soja e do milho e atributos físicos do solo. Revista Brasileira de Ciência do Solo, 39: 243-255, 2015.

VINHAL-FREITAS, I. C.; RODRIGUES, M. B. Fixação Biológica do Nitrogênio na cultura do milho. Agropecuária Técnica, v. 31, n. 2, 2010. 